$$
\begin{aligned}
& \text { Johan wahyudi, Ahmad Shalludin, dan Yuslena Sari. Deteksi Kandungan Unsur Hara Daun } \\
& \text { Jagung Menggunakan K-Nearest Neighbor (KNN) }
\end{aligned}
$$

\title{
DETEKSI KANDUNGAN UNSUR HARA DAUN JAGUNG MENGGUNAKAN K-NEAREST NEIGHBOR
} (KNN)

\author{
Johan wahyudi'), Ahmad Shalludin' ${ }^{2}$, dan Yuslena Sari ${ }^{3)}$ \\ I)Teknik Informatika, STMIK Indonesia Banjarmasin \\ 2) Manajemen Informatika, STMIK Indonesia Banjarmasin \\ ${ }^{3)}$ Program Studi Teknologi Informasi, Fakultas Teknik, Universitas Lambung Mangkurat \\ Email : johan77@stmik.id'), roselanil976@gmail.com²), yuzlena@ulm.ac.id ${ }^{3)}$
}

\begin{abstract}
ABSTRAK
Tanaman jagung memerlukan unsur hara untuk kelangsungan hidupnya. Dari unsur hara tanaman ada tiga unsur utama seperti Nitrogen(N), Fosfor(P), dan Kalium(K). Namun dalam prakteknya untuk mengetahui kekurangan unsur hara tanaman jagung melalui daunnya memerlukan beberapa alat yang harganya mahal sehingga tidak efesien. Dengan adanya cara untuk mengetahui kekurangan unsur hara melalui pengolahan citra digital diharapkan dapat membantu para petani dalam penangganan kekurangan unsur hara lebih mudah dan efesien. Pada penelitian ini penerapan sistem pengolahan citra digital menggunakan RGB metode ektraksi Hue, Saturation, Value (HSV) setelah di dapatkan nilai rata-rata RGB dan HSV, kemudian dilakukan proses pengklasifikasian dengan metode K-Nearest Neighbor (KNN). Data sampel menggunakan 5 klasifikasi citra data training dengan masing-masing 5 data testing pada setiap citra data training dengan hasil akurasi sebesar $80 \%$ sistem dapat mendeteksi citra daun jagung.
\end{abstract}

Kata Kunci : Daun Jagung, Unsur Hara N, P, K, Citra Digital, RGB, HSV, K-Nearest Neighbor.

\section{ABSTRACT}

Corn plants need nutrients for survival. Of the plant nutrients, there are three main elements such as Nitrogen $(N)$, Phosphorus $(P)$, and Potassium (K). However, in practice, to see the shortcomings of the maize plant through its leaves requires several expensive tools so that it is not efficient. In a simple way to see the shortcomings that cannot be done through digital image processing, it is hoped that it can help farmers in dealing with shortcomings that are no easier and more efficient. In the research on the application of digital image processing systems using the RGB extraction method Hue, Saturation, Value (HSV) after obtaining the average RGB and HSV values, then the classification process is carried out using the K-Nearest Neighbor (KNN) method. The sample data uses 5 classifications of training data image data with 5 testing data for each training data image with an accuracy of $80 \%$. The system can produce an image of corn leaves.

Keywords: Corn Leaves, N, P, K Nutrients, Digital Image, RGB, HSV, K-Nearest Neighbor.

\section{PENDAHULUAN}

Tanaman jagung termasuk dalam keluarga rumput dengan spesies Zea mays L. Morfologi tanaman jagung termasuk tanaman berakar serat dengan batang tidak bercabang, silindris dan terdiri dari beberapa segmen dan buku gabungan[I] Jagung merupakan tanaman pangan yang banyak di tanam oleh petani di Indonesia setelah tanaman padi. Berdasarkan data dari Kementerian Pertanian tahun 2010 sampai 2014 , mengalami peningkatan produktivitas sekitar $2,67 \%$ pertahun, walaupun luas panen mengalami penerunan sekitar -I,77\% pertahun[2].

Tanaman jagung memerlukan unsur hara untuk kelangsungan hidupnya. Dari unsur hara tanaman ada tiga unsur utama Nitrogen $(\mathrm{N})$, Fosfor $(\mathrm{P})$, dan $\operatorname{Kalium}(\mathrm{K})$. Untuk memenuhi unsur $P$ sampai stadia lanjut, tanaman jagung khusunya pada saat tanaman muda gejala defisiensi fosfor terlihat saat tanaman belum setinggi lutut dan tepi daun berubah menjadi gelap. Kalium pada tanaman jagumg diambil sejak tanaman setinggi lutut sampai selesai pembungaan. Gejala saat kekurangan unsur Kalium terlihat pada daun jagung terutama pada daun yang telah tua akan berbentuk keriting. Akhirnya akan menimbulkan bercak merah kecoklatan dan daunnya menjafi keriting dan mati[3][4].

Dalam penelitian sebelumnya, yang dilakukan oleh I Wayan Astika dkk tentang pengukuran tingkat warna daun dengan obyek daun padi dengan judul "Pengukuran Tingkat Warna Daun Padi dan Dosis Pemupukan dengan telepon seluler Android". Penelitian ini bertujuan untuk memudahkan para petani mengetahui takaran penggunaan pupuk urea pada padi dengan melihat warna daun padi. Dari penelitian ini hasil akurasi yang didapatkan rata-rata $60 \%$, dan dapat mencapai $84 \%$ pada kondisi iluminasi rendah dengan memakai metode $\mathrm{K}-\mathrm{NN}(\mathrm{k}$-Nearest Neighbor). Dari penelitian lainnya yang dilakukan Adi Chris D.P.P. Bangun dkk, tentang kalibrasi warna daun berdasarkan BWD dengan judul "Implementasi metode kalibrasi warna relatif dan K-Nearest Neighbor pada 
Smartphone untuk akuisisi warna pada bagan warna daun"[5][6].

Penelitian ini bertujuan untuk mengatasi perpermaslahan petani dalam mengevaluasi keadaan tanaman menggunakan Smartphone berdasarkan foto daun. Dari penelitian ini akurasi yang didapatkan diatas $83 \%$ dengan memakai metode yang sama dengan penelitan sebelumnya yaitu metode kNN(k-Nearest Neighbor). Penelitian yang dilakukan Fungky Arya dengan judul "Klasifikasi warna daun padi dan pemupukan urea dengan metode warna hue saturation intensity dan metode fuzzy logic" dalam penelitian ini yang dibahas adalah pengklasifikasian warna daun padi dan tingkat kebutuhan pupuk urea (Nitrogen). Untuk mengetahui kebutuhan pupuk pada padi petani harus melihat warna daun padi. Dalam melihat warna daun dan menentukan kebutuhan pupuk, ada dua alat yang dapat digunakan yaitu Bagan Warna Daun (BWD) dan Chlorophyll meters[7].

Berdasarkan penelitian tersebut, maka dengan ini metode ektraksi warna dan metode K-NN(K-Nearest Neighbor) dapat digunakan pada penelitian klasifikasi warna daun jagung berdasarkan unsur hara menggunakan aplikasi mobile Smartphone Android dan dapat memudahkan petani untuk melakukan penangganan masalah kekurangan atau defisiensi unsur hara pada tanaman jagung.

\section{TINJAUAN PUSTAKA}

\section{I Pengolahan Citra Digital}

Pengolahan citra digital dimulai pada kisaran tahun 1920 yang berawal dari publikasi di media cetak, di mana sebuah citra dapat dikirim melalui kabel dibawah laut yang berada di London ke New York. Kemudian pada kisaran tahun 1960 diluncurkan sebuah komputer yang dapat melakukan pengolahan citra. Komputer tersebut yang menjadi pemacu perkembangan teknologi dalam pengolahan citra digital jadi lebih cepat[8]. Gambar dapat dijelaskan sebagai fungsi dua dimensi $f(x, y)$, dimana koordinat $x$ dan $y$ merupakan koordinat bidang datar dan fungsi $f$ dalam setiap pasang koordinat $(x, y)$ adalah tingkat abu-abu gambar dari gambar pada titik itu. misalkan $x, y$ dan $f$ semuanya terbatas, dan nilainya diskrit, gambar tersebut disebut gambar digital. Gambar citra digital terbentuk dari beberapa komponen hingga tiap lokasi dan nilai tertentu. komponen ini disebut sebagai picture element, image element, dan pixels[9].

\subsection{Daun Jagung}

Jagung mempunyai nama Zae mays $L$ termasuk dalam famili graminae. Jagung termasuk tumbuhan monokotil atau berbiji tunggal. Bentuknya menyerupai rumput dan tubuhnya lebih kuat. Jagung dapat tumbuh di tanah sawah pada musim kemarau (bulan April - September). Jika ditanam di sawah tegalan/pekarangan, jagung ditanam pada musim hujan atau labuh (bulan Oktober-Nopember). Yang penting tanah harus gembur dengan lapisan tanah yang tebal dan mengandung banyak humus. Tempat yang digunakan untuk menenam jagung yang baik yaitu yang memiliki curah hujan tidak terlalu lebat. Jagung tumbuh pada suhu $21^{\circ} \mathrm{C}-30^{\circ} \mathrm{C}$. Jagung juga bisa ditanam di daerah dataran tinggi yaitu antara $1000-1800 \mathrm{~m}$ diatas permukaan laut [10].

\subsection{Unsur Hara}

Tumbuhan membutuhkan makanan yang kerap disebut nutrisi tanaman. Tumbuhan menggunakan bahan anorganik untuk menperoleh energi dan pertumbuhan. Unsur yang bisa diresap untuk pertumbuhan dan metabolisme tanaman disebut nutrisi tanaman. Untuk mengubah mekanisme nutrisi tanaman sebagai senyawa organik atau energi disebut dengan metabolisme. Nutrisi tanaman fungsinya tidak bisa diubah oleh elemen lain dan jika tidak ada nutrisi tanaman, metabolisme bisa terganggu atau berhenti sama sekali. Umumnya pada tanaman yang mengalami kekurangan atau kekurangan nutrisi akan menunjukkan gejala pada bagian tertentu yang spesifik [II].

\subsection{Hue, Saturation, Value (HSV)}

Model HSV menunjukan bentuk tiga komponen ruang warna yakni hue, saturation, dan value (brightness). Hue merupakan sudut dari 0 hingga 360 derajat, biasanya 0 berwarna merah, 60 derajat berwarna kuning, 120 derajat berwarna hijau, 180 derajat berarna cyan, 240 derajat berwarna biru, dan 300 derajat berwarna magenta. Hue menyatakan jenis warna ( merah, biru, atau kuning) atau rona warna di mana warna tersebut ditemukan dalam spektrum warna. Merah, kuning, dan Ungu adalah jenis warna yang menunjukan hue. Saturation merupakan kadar sejumlah besar kemurnian pada warna tersebut. Sebagai contoh entitas warna yang semuanya berwarna merah tanpa ada warna putih adalah saturation utuh. Value atau bisa juga disebut intensitas (inten sity) yakni seberapa banyak kecerahan dari suatu warna atau bisa juga banyaknya cahaya yang berasal dari suatu warna. Value mempunyai nilai dari 0 hingga $100 \%[8]$.

2.5 K-Nearest Neighbor (KNN)

Metode KNN merupakan klasifikasi sekumpulan data yang didasarkan pada data pembelajaran yang telah 
diklasifikasikan sebelumnya. Termasuk dalam pembelajaran terawasi, di mana hasil kueri instance baru diklasifikasikan berdasarkan mayoritas kedekatan kategori dalam KNN. Dalam tahap training, metode hanya menjalankan mencadangkan vektor-vektor dari fitur dan klasifikasi data traning sample. Dalam tahap klasifikasi, hitunglah fitur-fitur yang sama untuk testing data (klasifikasinya tidak diketahui). Jarak vektor baru ke seluruh vektor traning sample dihitung dan jumlah nilai $\mathrm{k}$ yang terdekat diambil. Poin-poin yang baru klasifikasinya diprediksi tertera dalam klasifikasi tertinggi dari poin-poin tersebut. Untuk menentukan jarak dari dua poin yaitu poin dalam data traning $(x)$ dan poin dalam data testing $(y)$ maka rumus Euclidean digunakan sebagaimana yang ditunjukan dalam persamaan I berikut:

$$
D(x, y)=\sqrt{\sum_{k}^{n}-1\left(x_{k}-y_{k}\right)^{2}}
$$

Di mana $D$ adalah jarak antara poin-poin dalam data training $x$ dan poin data testing $y$ untuk diklasifikasikan, di mana $x=x I, x 2, \ldots, x i$ dan $y=y l, y 2, \ldots$, yi dan i mewakili nilai atribut dan $n$ adalah dimensi atribut[12].

\subsection{Android}

Android adalah sistem operasi berdasarkan linux yang perancangan pembuatannya di khususkan untuk perangkat seluler seperti ponsel cerdas (smartphone). Android merupakan sistem operasi yang bersifat open source, sehingga banyak dari programmer beramai-ramai untuk membikin aplikasi dan sistem dari android dapat di modifikasi. Sistem operasi Android telah dimulai dari tahun 2009 hingga saat ini[13].

dan pengutipan menggunakan teknik rujukan berkurung (nama, tahun). Pencantuman sumber pada kutipan langsung hendaknya disertai keterangan tentang nomor halaman tepat asal kutipan. Contoh: (Davis, 2003: 47).

Gunakan sistem author-date untuk menulis referensi, seperti '(Kosko, 1999)' atau 'menurut pendapat Kosko (1999) .... '. Gunakan nama belakang pengarang diikuti tahun terbit. Jika Anda ingin menghemat energi, akan lebih baik jika Anda menginstall aplikasi EndNote pada komputer Anda.

\section{METODE PENELITIAN}

\section{I Bahan dan Alat Penelitian}

Alat-alat yang dipakai untuk penelitian berupa hardware dan software. Dalam penelitian klasifikasi warna daun jagung berdasarkan kekurangan kandungan unsur hara ini, untuk perangkat keras yang digunakan, yaitu:

I. Komputer atau laptop, spesifikasi minimal Core i3, RAM 4 GB.

2. Kamera Smartphone, beresolusi minimal I3 MP.

Sedangkan perangkat lunak yang digunakan untuk penelitian ini seperti:

I. Matlab R2018a

2. Android studio.

\subsection{Perhitungan Sistem}

Dalam pembuatan perhitungan metode K-Nearest Neighbor ini akan digambarkan dengan menggunakan flowchart sebagai berikut :

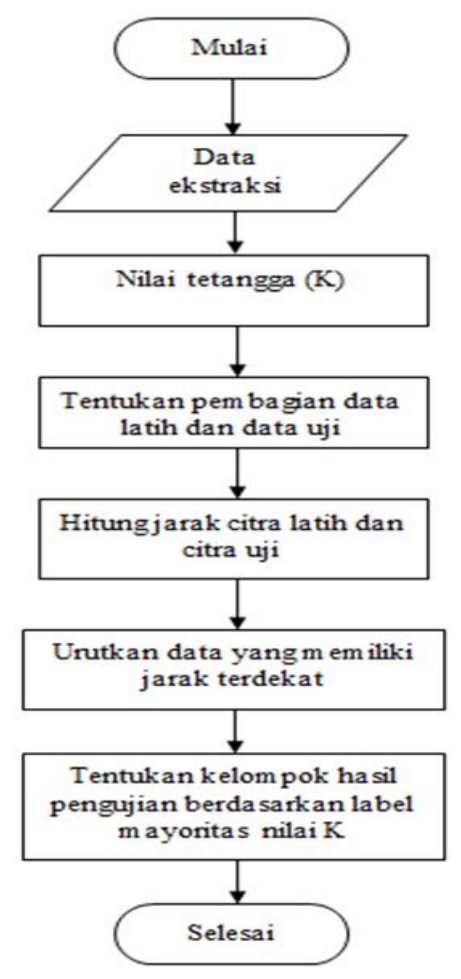

Gambar I Alur metode K-Nearest Neighbor

\subsection{Perancangan Aplikasi}

Dalam merancang sistem ini, proses data terbagi dalam dua tahap yakni data latih (traning) dan pengujian data (testing). Prosesnya bisa dilihat di gambar 2 berikut. 


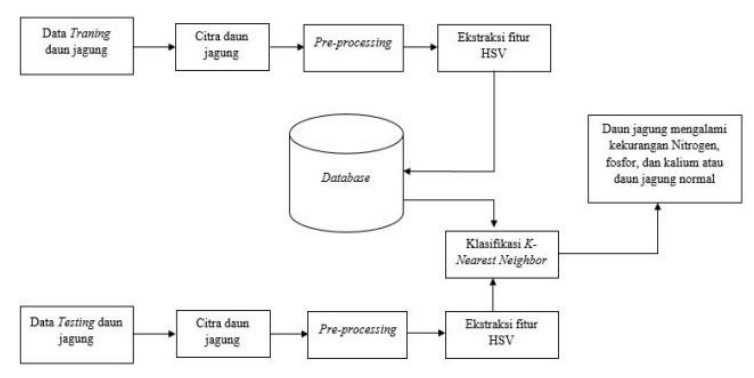

Gambar 2 Tahapan Perancangan Sistem

Gambar 2 diatas adalah perancangan sistem, dimulai dari data traning dari citra atau foto daun jagung dimasukkan ke dalam sistem yang ada di smartphone. Kemudian tahap selanjutnya yakni melakukan proses preprocessing dengan melakukan cropping terlebih dahulu pada citra daun jagung agar menjadi semakin nampak/jelas, mengatur kontras warna, menghilangkan noise, dan proses-proses lainnya. Setalah selesai melakukan preprocessing, dilakukanlah proses pengolahan citra digital dengan mengkonversi citra RGB ke metode Hue, Saturation, Value (HSV). Setelah dilakukan konversi citra ke HSV, kemudian nilai rata-rata dari masing-masing piksel HSV disimpan ke dalam database. Tahap selanjutnya melakukan perhitungan dengan menggunakan metode $K$ Nearest Neighbor. Kemudian didapatkanlah hasil daun jagung yang mengalami kekurangan unsur hara maupun daun jagung yang normal.

\section{I Pengambilan Data}

\section{HASIL DAN PEMBAHASAN}

Pengambilan data citra yang telah didapatkan merupakan hasil dari studi dilapangan. Pengambilan data citra bertempat di desa Padang Raya, Kecamatan Halong Kabupaten Balangan, Kalimantan Selatan. Dengan menggunakan kamera Ponsel Smartphone. Data yang diperoleh berjumlah sebanyak 117 gambar yang terdiri dari 20 gambar untuk data training daun normal, 19 gambar data daun kekurangan Nitrogen, 18 gambar data daun kekurangan Kalium, I5 gambar data daun kekurangan Fosfor, 20 gambar data daun kekeringan dan masingmasing 5 gambar sebagai data testing untuk setiap kategorinya. Untuk jumlah data ditentukan dengan membagi dua bagian, data training dan data testing. Dengan data training berjumlah 92 dan data testing berjumlah 25 data.

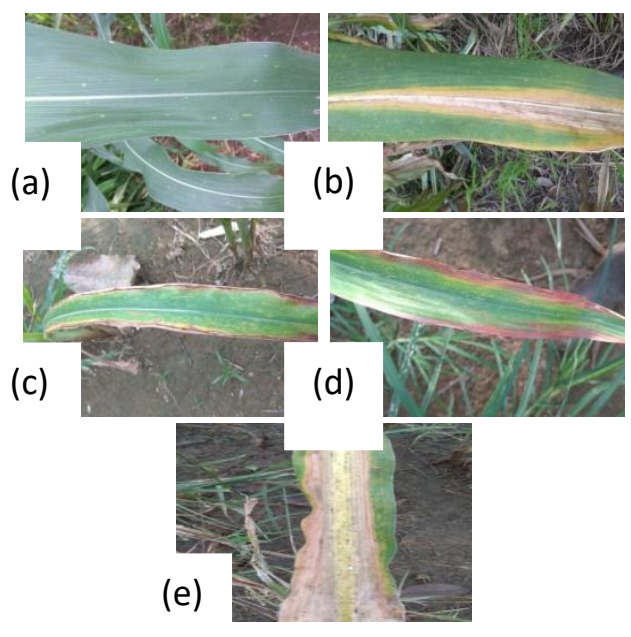

Gambar 3 (a) Daun Normal, (b) Daun kekurangan N, (c) Daun Kekurangan K, (d) Daun Kekurangan Fosfor, (e) Daun Kering.

\subsection{Pembahasan}

Berdasarkan data yang telah diperoleh tersebut, maka data nantinya akan diolah ke dalam sistem. Kemudian data akan melalui proses tahapan yakni Pre-processing. Tahapan proses ini dilakukan dengan mengcrop untuk mengambil bagian daun citra kemudian resize citra dengan ukuran 30x70 piksel. Dalam pengolahan data daun jagung ini terbagi menjadi dua bagian, yakni pertama mengolah data training terlebih dahulu kemudian lakukan pengolahan data terhadap data testing.

Data Testing yang digunakan terdiri dari 5 jenis daun yakni daun normal, Kekurangan Nitrogen, Kekurangan Kalium, Kekurangan Fosfor dan Kering dengan masing-masing berjumlah I data training. Pada data testing ini untuk labelnya sudah diketahui karena untuk memastikan bahwa perhitungan yang dilakukan sudah benar dan data testing ini juga telah diketahui jenis atau kekurangan unsur haranya sehingga dapat diketahui kesimpulan atau hasil perhitungan dengan data training.

Tabel I Data testing

\begin{tabular}{ccccccc}
\hline $\mathbf{R}$ & $\mathbf{G}$ & $\mathbf{B}$ & $\mathbf{H}$ & $\mathbf{S}$ & $\mathbf{V}$ & Label \\
\hline 165,407 & 165,548 & $|13,19|$ & 60 & 31,6 & 64,9 & 2 \\
192,661 & 204,399 & 133,817 & 70 & 34,5 & 80,2 & 3 \\
102,459 & 147,548 & 113,76 & 135 & 30,6 & 57,9 & 1 \\
163,844 & 151,272 & 157,985 & 328 & 7,7 & 64,3 & 4 \\
172,131 & 161,81 & 158,493 & 15 & 7,9 & 67,5 & 5 \\
\hline
\end{tabular}

Data dari Tabel I adalah data training dari keseluruhan daun. Kemudian Tabel 4.2 adalah data testing. Dari kedua tabel yang berisikan data RGB dan HSV perhitungan 
Euclidean distance pada fitur dengan cara membandingkan masing-masing fitur.

Tabel 2 Data testing label 2

\begin{tabular}{ccccccc}
\hline $\mathbf{R}$ & $\mathbf{G}$ & $\mathbf{B}$ & $\mathbf{H}$ & $\mathbf{S}$ & $\mathbf{V}$ & Label \\
\hline 165,407 & 165,548 & $|13,19|$ & 60 & 31,6 & 64,9 & 2 \\
\hline
\end{tabular}

Kemudian cari euclidean distance dengan rumus dari persamaan I. Data testing pada Tabel I diatas dibandingkan dengan data training. Hasilnya didapatkan nilai dari euclidean distance seperti dibawah ini.

$$
\begin{gathered}
D(x, y) \\
=\sqrt{\begin{array}{c}
(125.638-165.407)^{2}+(164.648-165.548)^{2}+ \\
(148.981-113.191)^{2}+(156-60)^{2}+ \\
(23.7-31.6)^{2}+(64.6-64.9)^{2}
\end{array}} \\
D(x, y)=110.18987
\end{gathered}
$$

Lakukan perhitungan ini ke seluruh data training dan data testing pada Tabel 2 Hasil perhitungan euclidean distance seluruh data bisa dilihat di Tabel 3 berikut.

Tabel 3 Hasil perhitungan euclidean distance data testing label 2

\begin{tabular}{lcc}
\hline DISTANCE & kl & k3 \\
\hline 94,82424339 & & \\
20,47207378 & & 2 \\
22,87837007 & & 2 \\
29,99157234 & & \\
19,45507846 & 3 & 3 \\
\hline
\end{tabular}

Pada data testing label 2 nilai $\mathrm{k}=\mathrm{I}$ ada pada label 3 tetapi karena hasilnya label 3 yakni kalium dan data yang seharusnya label 2 adalah Nitrogen maka kemudian di lihat di $\mathrm{K}=3$ karena ada tiga nilai pilih nilai yang terbanyak keluar, di sini ada dua nilai 2, jadi pada data testing label 2 ini hasilnya BENAR untuk data testing label 2 adalah Nitrogen.

\section{PENGUJIAN}

Dari proses pengolahan data hingga klasifikasi citra daun jagung mengalami defisiensi unsur hara tersebut dengan total data training yang digunakan adalah sebanyak 117 buah data training sedangkan total data testing yang digunakan adalah sebanyak 25 buah data testing, hasil antara masing-masing kategori daun jagung yaitu sebagai berikut:

\section{I) Daun Normal}

Dari 20 buah data training dan dari 5 data testing mendapatkan 5 buah data hasil. Adapun perbandingan ground truth dengan hasil sistem bisa dilihat pada Tabel 4 berikut:

Tabel 4 Pengujian hasil daun normal

\begin{tabular}{ccc}
\hline $\begin{array}{c}\text { Data } \\
\text { Citra } \\
\text { Daun }\end{array}$ & $\begin{array}{c}\text { Ground } \\
\text { Truth }\end{array}$ & Hasil \\
\hline I & Daun Normal & Daun Normal \\
2 & Daun Normal & Daun Normal \\
3 & Daun Normal & Daun Normal \\
4 & Daun Normal & Daun Normal \\
5 & Daun Normal & Daun Normal \\
\hline
\end{tabular}

2) Daun Jagung kekurangan $N$

Dari 19 buah data training dan dari 5 data testing mendapatkan 5 buah data hasil. Adapun perbandingan ground truth dengan hasilnya bisa dilihat pada Tabel 5 berikut:

Tabel 5 Pengujian hasil daun jagung kekurangan nitrogen

\begin{tabular}{ccc}
\hline $\begin{array}{c}\text { Data } \\
\text { Citra } \\
\text { Daun }\end{array}$ & $\begin{array}{c}\text { Ground } \\
\text { Truth }\end{array}$ & Hasil \\
\hline I & Daun Jagung \\
kekurangan N & Daun Jagung \\
kekurangan N \\
2 & Daun Jagung & Daun Jagung \\
kekurangan N & kekurangan N \\
& Daun Jagung & Daun Jagung \\
& kekurangan N & kekurangan N \\
3 & Daun Jagung & Daun Jagung \\
& kekurangan K \\
4 & Daun Jagung & Daun Jagung \\
& kekurangan N & kekurangan K \\
\hline
\end{tabular}

3) Daun Jagung Kekurangan $K$

Dari 18 buah data training dan dari 5 data testing mendapatkan 5 buah data hasil. Adapun perbandingan ground truth dengan hasil bisa dilihat pada Tabel 6 berikut:

Tabel 6 Pengujian hasil daun jagung kekurangan Kalium

\begin{tabular}{lcl} 
Data & Ground & Hasil \\
Citra & Truth & \\
Daun & & \\
\hline
\end{tabular}




\begin{tabular}{ccc}
\hline I & Daun Jagung & Daun Jagung \\
kekurangan K & Normal \\
2 & Daun Jagung & Daun Jagung \\
kekurangan K & kekurangan K \\
& Daun Jagung & Daun Jagung \\
3 & kekurangan K & kekurangan K \\
& Daun Jagung & Daun Jagung \\
4 & kekurangan K & kekurangan $\mathbf{N}$ \\
& Daun Jagung & Daun Jagung \\
& kekurangan K & kekurangan K \\
\hline
\end{tabular}

\section{4) Daun Jagung Kekurangan $F$}

Dari 15 buah data training dan dari 5 data testing mendapatkan 5 buah data hasil. Adapun perbandingan ground truth dengan hasil sistem bisa dilihat pada Tabel 7 berikut:

\begin{tabular}{ccc}
\multicolumn{3}{c}{ Tabel 7 Pengujian hasil daun jagung kekurangan Fosfor } \\
\hline $\begin{array}{c}\text { Data } \\
\text { Citra } \\
\text { Daun }\end{array}$ & $\begin{array}{c}\text { Ground } \\
\text { Truth }\end{array}$ & Hasil \\
\hline I & Daun Jagung & \\
& kekurangan F & Daun Jagung \\
kekurangan F \\
2 & Daun Jagung & Daun Jagung \\
& kekurangan F & kekurangan F \\
& Daun Jagung & Daun Jagung \\
3 & kekurangan F & kekurangan F \\
& Daun Jagung & Daun Jagung \\
4 & kekurangan F & kekurangan F \\
& Daun Jagung & Daun Jagung \\
& kekurangan F & kekurangan F \\
\hline
\end{tabular}

\section{5) Daun Jagung Kering}

Dari 20 buah data training dan dari 5 data testing mendapatkan 5 buah data hasil. Adapun perbandingan ground truth dengan hasil bisa dilihat pada Tabel 8 berikut:

Tabel 8 Pengujian hasil daun jagung kering

\begin{tabular}{ccc}
\hline $\begin{array}{c}\text { Data } \\
\text { Citra } \\
\text { Daun }\end{array}$ & $\begin{array}{c}\text { Ground } \\
\text { Truth }\end{array}$ & Hasil \\
\hline I & $\begin{array}{c}\text { Daun Jagung } \\
\text { kering } \\
\text { Daun Jagung } \\
\text { kering } \\
\text { Daun Jagung } \\
\text { kering }\end{array}$ & $\begin{array}{c}\text { Daun Jagung } \\
\text { kekurangan K } \\
\text { Daun Jagung kering }\end{array}$ \\
2 & Daun Jagung kering \\
&
\end{tabular}

\begin{tabular}{ccc}
4 & $\begin{array}{c}\text { Daun Jagung } \\
\text { kering } \\
\text { Daun Jagung } \\
\text { kering }\end{array}$ & Daun Jagung kering \\
& Daun Jagung kering \\
\hline
\end{tabular}

Dari seluruh hasil pada pengujian sistem maka klasifikasi yang didapatkan untuk proses pengujian akurasi dengan tiap-tiap jenis defisiensi unsur hara tanaman jagung yang dirincikan bisa dilihat pada Tabel 9 berikut

Tabel 9 Hasil Seluruh Pengujian Sistem

\begin{tabular}{cccccc}
\hline & Nrml & N & K & F & Krg \\
\hline $\mathbf{N r m l}$ & 5 & 0 & 0 & 0 & 0 \\
$\mathbf{N}$ & 0 & 3 & 2 & 0 & 0 \\
$\mathbf{K}$ & 1 & 1 & 3 & 0 & 0 \\
$\mathbf{F}$ & 0 & 0 & 0 & 5 & 0 \\
$\mathbf{K r g}$ & 0 & 0 & $\mathrm{I}$ & 0 & 4 \\
\hline
\end{tabular}

Keterangan:

$$
\begin{array}{ll}
\mathrm{Nmrl} & =\text { Daun Normal } \\
\mathrm{N} & =\text { Daun Kekurangan Nitrogen } \\
\mathrm{K} & =\text { Daun Kekurangan Kalium } \\
\mathrm{F} & =\text { Daun Kekurangan Fosfor } \\
\mathrm{Krg} & =\text { Daun Kering }
\end{array}
$$

Pada Tabel 9 dapat dilihat perbandingan hasil seluruh pengujian sistem dapat dilanjutkan untuk proses pengujian akurasi, sehingga tingkat keakuratan dari sistem bisa dihitung sebagai berikut:

$$
\begin{aligned}
\text { Classification Accuracy }= & \frac{\mathrm{TP}}{\text { Total Dataset }} \times 100 \% \\
& =\frac{20}{25} \times 100 \% \\
& =80 \%
\end{aligned}
$$

Jadi dari perhitungan di atas didapat tingkat keakuratan hasil sistem adalah $80 \%$.

\section{I Kesimpulan}

\section{PENUTUP}

Berdasarkan pengujian dan analisis dalam penelitian Klasifikasi Warna Daun Jagung Berdasarkan Kekurangan Kandungan Unsur Hara Menggunakan HSV dan K-Nearest 
Neighbor (KNN) mendapatkan kesimpulan-kesimpulan sebagai berikut.

I. Aplikasi untuk klasifikasi kekurangan unsur hara telah berhasil dibuat dengan menggunakan metode $K$ Nearest Neighbors aplikasi tersebut dibuat berbasis android.

2. Sistem berhasil menerapkan metode K-Nearest Neighbors sebagai metode klasifikasi dengan hasil tingkat akurasi sebesar $80 \%$.

3. Waktu dan proses yang dibutuhkan dalam melakukan klasifikasi kekurangan unsur hara tidak memakan waktu yang lama.

4. Citra daun yang difoto dengan tidak benar dapat mengakibatkan citra daun jagung tidak terlihat dengan jelas hal ini dapat mempengaruhi hasil akhir pada sistem.

5. Faktor cahaya dapat mempengaruhi hasil citra.

berbagai kesimpulan yang diambil berdasarkan penelitian yang telah dilakukan. Berisi pernyataan singkat tentang hasil yang disarikan dari pembahasan. Saran dapat dituliskan pada bagian paling akhir.

\section{DAFTAR PUSTAKA}

[I]. Purwono and R. Hartono, Bertanam Jagung Unggul. Jakarta: Penebar Swadaya, $20 \mid 4$.

[2]. Kementerian Pertanian, "Renstra Kementrian Pertanian Tahun 2015 - 2019," 2014, Pp. I-339, 2014, doi: 351.077 Ind r..

[3]. Suprapto and A. M. Rasyid, Bertanam Jagung. Jakarta: Penebar Swadaya, 2005.

[4]. Belajartani.com, "Cara mudah mengukur kekurangan unsur hara plant deficiency guide dari daun tanaman," 2016. [Online]. Available: https://belajartani.com/cara-mudah-mengukurkekurangan-unsur-hara-plant-deficiency-guide-daridaun-tanaman/. [Accessed: 2I-Nov-2019].

[5]. I. W. Astika, Sugiyanta, and M. M. Cibro, "Pengukuran Tingkat Warna Daun Padi Dan Dosis Pemupukan Dengan Telepon Seluler Android," Pros. InSINas, pp. 43-49, 2012.

[6]. A. C. D. P. P. Bangun, H. Ginardi, and C. Fatichah, "Implementasi Metode Kalibrasi Warna Relatif," vol. 2, no. I, 2013.

[7]. F. Arya, "Klasifikasi Warna Daun Padi Untuk Menentukan Dosis Pemupukan Urea Dengan Metode Warna Hue Saturation Value dan Fuzzy Logic," 2018.
[8]. D. Putra, Pengolahan Citra Digital. Yogyakarta: C.V Andi Offset, 2010.

[9]. Hermawati and F. Astuti, Pengolahan Citra Digital konsep dan teori. Yogyakarta: C.V Andi Offset, 2013.

[10]. Mashudi, Bercocok Tanam Palawija. Azka Press, 2007.

[II]. A. Rosmarkam and N. Widya Yuwono, Ilmu Kesuburan Tanah. Yogyakarta: Penerbit Kanisius, 2002.

[12]. A. M. Siregar and A. Pusphabuana, Data mining: pengolahan informasi data dengan rapid miner. Surakarta: Kekata Grup, 2017.

[13]. A. A. Huda, Livecoding! 9 Aplikasi Android buatan sendiri. Yogyakarta: Penerbit Andi, 2013. 